\title{
The Influence of Social Media on Early Childhood Growth in the Era of the NET Generation
}

\author{
Annisa Salma Fadilah \\ Universitas Negeri Semarang, Semarang, Indonesia \\ e-mail: annisasalma2022@gmil.com
}

\begin{abstract}
Advances in Science and Technology have a significant impact on the life line of society. One of them is social media that makes communication easier. Social media is no longer a new thing in the community. Starting from adults, teenagers, children to toddlers now have social media accounts. Like Instagram, YouTube, and Facebook. Early childhood is a time of exploring and imitating. What is in his environment will certainly affect his mindset and lifestyle. In this digital era, we often find a variety of social media accounts owned by children after an early age, whereas in general they cannot use social media. This will certainly influence the growth of early childhood, especially on aspects of children's moral development, social-emotional development, motor development, and language development in children. The purpose of this article is to analyze the influence of social media on early childhood growth and development. According to a literature review that has been carried out, there are several benefits of social media in child development and on the other hand shows the many negative influences of social media on early childhood development. Like the number of speak delay, gaming disorder, kidnapping, extortion, fraud, and the worrying thing for early childhood is that they cannot tell which virtual world is in social media and the real world, because the concept that he gets more about cyberspace through social media. Patterns of fostering and coaching from relevant stakeholders are needed to anticipate addiction and prevent negative impact from social media itself.
\end{abstract}

Keywords: early childhood, influence, social media

\section{INTRODUCTION}

Advances in Science and Technology have a significant impact on the side of people's lives. One of the goals of technological progress is in terms of patterns of communication and social interaction. Currently, to be able to communicate remotely, the public no longer has to bother with many advanced technologies that can access applications to make it easier to communicate. One means that can be used is through social media. The sophistication of cyberspace has changed the order of social interaction in society. A long time ago when I wanted to contact a distant relative, someone had to send a message through a sign of smoke, Wessel, and a letter, which certainly took a long time.
The existence of social media today not only makes it easy to communicate, but can be a medium of entertainment, media to obtain information, add relationships, find old friends, and even become a promising business for people who can use. Social media users are also increasingly indiscriminate from adults, teenagers, children, to toddlers and even toddlers are also the target of social media progress.

Human interaction with humans has been replaced by interaction through digital technology and often it is not realized that this can reduce a person's direct interaction with the closest people around, for example between parents and children in their homes busy with their gadgets. Even though the gadget is not at all a child's primary need (Alia Tesa \& Irwansyah, 2018: 65). 
Childhood is the beginning of human life. The complexity of human life in childhood, especially in early childhood, becomes the main foundation for human development at a later age, such as adolescence and adulthood. The complexity of child development at an early age requires a lot of stimuli until the development can reach an optimal point. Humans begin their life journey in infancy by learning what is around them. Babies begin to learn things around them through experiences experienced as part of their learning process in knowing life. All aspects and components that affect human life from birth require a perfect combination of genetic and environmental factors to be able to provide the best learning experience (Alia Tesa \& Irwansyah, 2018: 66).

Digital technology is an important aspect of the factors that influence child development. The inclusion of digital technology in the developmental life of children invades many stages of development that children should achieve. Technology makes their lives faster (instant) and more efficient. Entertainment technologies such as television, internet, video games, iPods, iPads, and others have grown so rapidly that they make families almost unaware of the significant impact and lifestyle changes in their families (Rowan, 2013).

Parents have very important roles and responsibilities towards the family. Every parent wants his child to be a person who has a good personality. The family is the first social environment that children encounter to see and enjoy the world. Interaction with parents and the environment in the family becomes an experience that will later shape children's interactions with others. Child's relationship with parents and family is the first relationship that children encounter. Child relationships with parents and other family members can be considered as a system that interacts with each other. Through the attitude and parenting style of the child towards the child will give effect to the child both directly and indirectly (Nahriyah S, 2017: $65)$.

The development of an increasingly sophisticated era of all modern, parents is required to be more extra careful in maintaining, guiding, paying attention to children's growth and development. So that children do not fall into the negative effects of the development of the era. Parents must be able to understand and follow the development of technology so that they can guide and direct children when using the technology.
Because every technology has a positive and negative impact (Nahriyah S, 2017: 66).

The purpose of this article is to determine the influence of social media on early childhood development.

\section{METHOD}

The method used in this research is the method of literature study, namely:

Step1: Formulate the problem, determine the problem topic that will be discussed then link it with the solution of the problem that has been created from the existing solution.

Step 2: Search Literature

1) Search literature articles that are relevant to the topic of the problem, namely parenting

2) Get an overview of the research topic

3) The source of the article source is very helpful if supported by the knowledge of the topic being studied.

4) The source of the source provides an overview/summary of the previous research

Step 3: Evaluate Data

1) Look at any contribution to the topic discussed

2) Search and find the right data source as needed to support article writing

3) Data in the form of qualitative data, quantitative data and data derived from a combination of both.

Step 4: Analysis and Interpretation, the last step is to discuss and find and summarize the literature that will be made based on available data

\section{RESULT AND DISCUSSION}

\subsection{Social Media}

Media according to the Great Indonesian Language Dictionary (KBBI 2018), the media is a means or means of communication such as newspapers, magazines, radio, television, films, posters, and banners located between two parties.

According to Wikipedia (2018), social media is an online media, with its users being able to easily participate, share and create content including blogs, social networks, wikis, forums, and the virtual world.

Andreas Kaplan and Michael Haenlein define social media as "a group of Internet-based applications that build on the basis of Web 2.0 
ideology and technology, and which enable usergenerated content creation and exchange".

Social media is a means, means, tool or container to support harmony in socializing, which is why he is called social media, people who are anti-social should not be social media, or permissible, provided that the media becomes a psychic therapeutic tool for their future ( people who are anti-social) can change and have high social integrity (Alim M, 2018).

Social media is an online media that allows users to participate, share and create content (Herlanti Y, 2016). Social media has great potential to be developed in education in Indonesia, viewed from two sides, namely the number of users. The number of social media users in Indonesia is quite large, especially weblog and Facebook users. On June 24, 2012, the Silangsilang site recorded the number of weblog (blogger) users as many as $6,022,539$ and the socialbakers site recorded the number of Facebook users on February 1, 2013, totaling 48,777,600. According to Bosman Zagenczyk (in Herlanti, 2016) social media has the nature of relating, sharing, and collaborating (connecting, sharing, and collaboration).

Social media in its current role has built a great power in shaping patterns of behavior and various fields of human life. This makes the function of social media very large. The functions of social media include the following:

1. Social media is a medium designed to expand human social interaction using the internet and web technology.

2. Social media successfully transforms the practice of communication in the direction of broadcast media from one media institution to many audiences (one to many) into the practice of dialogical communication between many audiences (many to many).

3. Social media supports the democratization of knowledge and information. Reforming humans from users of the message content to the creator of the message itself.

Social media has characteristics that cannot be separated from the various characteristics of social media that are widely used today. Here are some characteristics found on social media according to http://www.artikelsiana.com/2017/09/pengertianmedia-social-fungsi.html:

1. Participation. Encourage contributions and feedback from everyone who is interested or interested in using it, so that it can blur the boundaries between media and audience.

2. Openness. Most of the social media is open to feedback and also participate through means of voting, various, and also comments. Sometimes the limitation is to access and also take advantage of the message content (password protection against content tends to be considered strange).

3. Conversation. In addition, it is possible to have conversations or users in two directions.

4. Connectivity. The majority of social media thrives because of an ability that can serve connectivity between users, through a facility of links to websites, sources of information and for other users.

Social media is divided into 6 (six) types: blogs, social networks (social networks), microblogs (microblogging), media sharing services, forums and collaboration services (http://yellowcabin.com/mengenal-6 social media type.

In this era children also act as users of social media, such as in Instagram, YouTube, and Facebook children under 3 years old already have a personal account and many uploads about him, both in the form of photos and videos. Parents as account holders will be proud of the photos and videos uploaded about their children are seen and liked by many people. Even because they are too happy, sometimes parents go too far making their children as money search engines by publishing children's photos and videos.

Based on the results of research conducted by The Asian Parent Insights in November 2014, as many as 98 percent of 2,714 parents in Southeast Asia who participated in this study allowed their children to access technology in the form of computers, smartphones, or tablets. This study was conducted on 2,714 parents in Southeast Asia who have children aged 3-8 years. The parents of the study participants came from Singapore, Malaysia, Thailand, Indonesia and the Philippines. From the survey results, most parents allow their children to play gadgets for educational purposes. But in fact, according to the survey results, most of their sons and daughters use the gadget/tablet for entertainment purposes such as games (Unantenne, 2014).

The sophistication and ease of operation of technology have caused children who are even early in age to be able to operate the products of technological sophistication. Technology offers 
convenience and variety in the child's process of learning many things. Technology that allows bringing sound and visual stimuli at the same time makes children able to learn many things at a time. Especially since the advent of multifunctional smartphones with more affordable prices has resulted in more people being able to have them. Even in certain families, gadgets may have been owned by school children ranging from elementary, middle and high school, including those who are still under five (Alia Tesa \& Irwansyah, 2018).

Many parents finally have provided technology to children. Without being noticed by parents, many children are already addicted to gadgets. This is still considered trivial by parents because parents consider that now is the digital era that is the era of using gadgets. If you haven't used a gadget, it's still out of date. Parents do not understand that gadget addiction is very dangerous for children because gadget addiction can interfere with children's physical and psychological (Alia Tesa \& Irwansyah, 2018).

Now, the time children spend with the media every day is more. Time spent watching television averages 3 hours on the school day and 7.4 hours on holidays, playing time for electronic games 3.8 hours and time spent playing internet on average 2.1 hours. Data from Nielsen Media shows that one in every four television viewers in Indonesia is a child, and the time spent by children watching television averages three hours per day (Hendriyani et al. 2012). The current era of digitalization has led to media convergence that allows children to become active participants. Child active participation in the digital era is a social phenomenon that needs to be studied (Corsaro, 2005).

As a result of technological advances, many creative and challenging games that turned out to be much favored by children. And this is indirectly very beneficial for children because it greatly influences the level of children's creativity. Some things that are a positive impact of information technology development (Susanto in Alia Tesa \& Irwansyah, 2018), among others:

1. Can add to your child's insight.

2. Children can build relationships, multiple friends, without having to be limited in distance and time.

3. Can facilitate children in finding and knowing the latest information.

4. Children can use an educational software technology such as programs for basic knowledge of reading, numeracy, history, geography, and so on. With the development of technology now educational devices can be made with elements of entertainment related to the educational material so that children indirectly want to learn (children's song videos).

5. Become a solution for parents who face a child who is tired of learning.

6. Building children's creativity.

7. Technology makes a child much more fluent in technology, especially information technology.

The presence of digital technology does provide many benefits for humans. Work can be done easily, and the information is more quickly accessed by the internet. But behind it all, there are a million threats lurking, especially in children. They are willing to spend most of their time with the gadget compared to playing in their neighborhood. What a sad reality, the gadget has become a new life for them. The following are the negative impacts and side effects of the use of digital technology (Rachman, 2016), including:

1. Decreasing learning achievement due to excessive use.

2. Limiting physical activity needed for child growth and development.

3. The development of children's social and language skills is hampered because they have been introduced to early gadgets (especially under 2 years of age).

4. Brain development is not maximal because of unbalanced developmental stimulation.

5. Eye health problems (screen time should be limited to a maximum of 2 hours per day).

6. Concentration problems (intermittent viewing and checking of gadgets).

7. Sleep problems, amount of sleep, and lack of sleep quality (due to the content of the spectacle).

8. There is no privacy, allows retrieval of personal data, child predators, cyberbullying, and others.

9. Problems with pornography, violence, or the cultivation of negative values.

\subsection{Early Childhood Growth}

What is meant by the understanding of early childhood is that children aged between 0 to 5 years are golden ages, ages that determine their future if they are well cared for, they will become children 
who can be expected to be useful for their nation (Hermoyo, 2015).

Hurlock (in Desmita, 2013) explains that childhood begins after passing through a dependent baby, that is, about 2 years of age until the child is sexually mature, which is approximately 13 years for women and 14 years for men. During this period there were a number of significant changes, both physically and psychologically. A number of experts divided children's time into two, namely early childhood and late childhood. The early childhood period lasts from 2 years to 6 years, and the end of childhood is 6 years old until the child is sexually mature.

Early childhood also has the characteristic of being able to try something and do things that are done by adults. Activities and activities played by adults, children begin to emulate movements in a simple way with a sense of pleasure and joy. At the age of 0-2 years, the child's ability is limited to reflexes, initial language, current time and close space. Characteristics of early childhood in communicating (Hermoyo, 2015):

1. The child communicates using words and gestures.

2. Children's language skills continue to be encouraged to help children express their desires and establish relationships with others.

When communicating with early childhood, parents need not be ashamed, for example, must act as a clown in front of a child, if in that way the child will be better able to understand and understand what parents mean (Andrianto, 2014). Early childhood is when a person experiences rapid development and growth in his life. Therefore, early childhood requires a variety of stimuli that can help them to develop well according to their needs and potential.

Growing is a physical change that can easily be measured. Developing is the increasing ability of the body's structure and function to become more complex. Growth is the occurrence of quantitative changes, which can be measured. The emphasis is on the physical. Your child's growth can be monitored by measuring the height, head circumference, weight, and standard size that has been agreed upon internationally. The development is the increase in the ability of the structure and function of the body that is very complex, Suppose your child has walked and talked. While development is observed from how to play, learn, speak, and also behave (Seefeldt, Wasik, \& Seefeldt, 2006).

Child development takes place most rapidly in the age of 0-3 years. After that, the process of child growth and development will continue continuously. In this phase, Mam needs to always monitor the progress on a regular basis to ensure that the process runs according to the stages of the child's age.

This periodic monitoring is also needed to detect early the possibility of disruption in child development. Disturbances or obstacles in the development of children that are quickly found will certainly be easier to handle so that the optimal growth and development process can be achieved. In general, there are three main factors that influence child development (Soejatiningsih, 1995):

1. Genetic factors such as gender, race (ethnicity), congenital factors that are pathological (certain diseases).

2. Living environment, weather and sanitation factors.

3. Factors for the intake of nutrients consumed by children every day.

The main parameters of child growth and development generally refer to four aspects of early childhood development (Dhiva A. A, 2015):

1. Aspects of physical development. This aspect includes weight gain, height, and gross motor and fine motor skills.

2. Aspects of cognitive development. Aspects of cognitive development of children can be divided into four stages; sensorimotor (0-24 months), preoperational (2-7 years), concrete operations (7-11 years), formal operations (aged 11 years and over).

3. Aspects of language development. This aspect relates to the child's ability to respond to sound, speak, communicate, follow orders, and so on. Children's language skills grow and develop rapidly during the preschool period. Through language skills can also be detected delays in other systems, such as cognitive abilities, sensorimotor, psychological, emotional, and the environment around the child.

4. Aspects of socio-emotional development. This aspect refers to the development of children's ability to interact and socialize with their environment. In addition, this aspect is related to the child's independent abilities such as eating alone, cleaning up toys after playing, and separating from parents. 
Parents also need to understand that the speed of development each child is different. In fact, the growth stage of boys and girls also has a number of differences. The most important thing for children is healthy and grow and develop optimally.

\subsection{Net Generation}

Since the internet boomed around 1996, plus a wave of social media, most of the world's population has "changed". The characteristics of the generation born after the boom of digital technology also differ from previous generations. For generation $\mathrm{Z}$ or better known as generation net (born in the era after 1995 or 2000), almost all of them were exposed to technology from a very early age.

Net generation has a good and bad view of children. With their practical life they rarely go through a long process. for example in this era they use social media more often to communicate than to chat directly or often spend time playing gadgets. This results in a low sense of empathy do not take the initiative to foster relationships around and forget to interact in the surrounding environment. Here is the role of parents as leaders who have control over directing children's behavior, children are given freedom of responsibility, following the rules of parents.

According to psychology Elizabeth T Santosa (in http://wartakota.tribunnews.com /2015/04/19/ kenali-generasi-net) said that parents must understand and assess the current generation. The key is not flat and there must be dynamics. "Young people need a leader figure, parents don't lose with gadgets. So knowledge must be continually upgraded".

Parents should educate children about the concept of process, endurance, and commitment in completing tasks. For example, children want to become singers, parents, and children design roadmaps to their destinations. At the age of five years of attending a singing course, the age of nine starts to be encouraged so that children make songs and release themselves (Setyaningsih Lilis, 2015).

Tapscott (2009) states that Net Gener brings demographic muscles, media intelligence, purchasing power to new models for collaboration and ways to become parents, entrepreneurship, and political power into the world. There are eight norms that distinguish Gener Net from previous generations. The norm's norms are:

\author{
1. Freedom \\ 2. Customization \\ 3. Investigation \\ 4. Integrity \\ 5. Collaboration \\ 6. Entertainment \\ 7. Speed \\ 8. Innovation
}

Tapscott (2009) stated not to scapegoat the internet, a global system for communication from various knowledge. This is the same as blaming the library because many people are stupid.

Net Generation Giving good and bad impact depends on the absorption of children in technological development, parents as leaders direct children in the use of the internet, and parents must always update information and use technology, parents must ensure children's mental readiness in the face of the Net Generation all practical and easy to get information.

\section{CONCLUSION}

The rapid advancement of Science and Technology provides many conveniences for people to access information and to communicate. Of course, these technological advances must be addressed wisely and appropriately in order to provide benefits for families, especially in educating children. The rapid advancement of modern technology has made new digital technology products such as smartphones, computers, various virtual social networks as primary needs all connected using the Internet. It cannot be denied that the internet offers various types of entertainment for every parent, young person, and also children. But of course, these technologies cannot be held responsible for the impact they have.

There are several benefits of social media in early childhood development and on the other hand, also shows the many negative influences of social media on early childhood development. Like the number of speech delay, gaming disorder, kidnapping, extortion, fraud, and the worrying thing for early childhood is that they cannot tell which virtual world is in social media and the real world, because of the concept that he gets more about cyberspace through social media.

Raising children in this information age has its own challenges. If parents are not good at anticipating it, children are not experts or users of information technology but are victims. Playing 
gadgets don't always have a bad impact. As long as it is used appropriately and according to the age of the child, the gadget can be useful. Among them as interactive learning media, a means of honing creativity, and providing support for children who have different learning needs (Alia Tesa, 2018).

\section{REFERENCES}

[1] Alia Tesa \& Irwansyah. (2018). Pendampingan Orang Tua pada Anak Usia Dini dalam Penggunaan Teknologi Digital. A Journal of Language, Literature, Culture, and Education POLYGLOT. 14(1). 65-75

[2] Alim M. (2018). Bunga Rampai Media Sosial. SPANSI MEDIA.

[3] Andrianto, D. (2014). Komunikasi efektif ortu untuk anak usia dini. Retrieved March 10, 2017, from Cahaya Ilmu: http://cahayailmu.com/index.php/9-uncategorised/89komunikasi-efekti-ortu-untuk-anak-usia-dini

[4] Corsaro, W. A. (2005). Collective action and agency in young children's peer culture (In J. Qvortrup. Studies in modern childhood: Society, agency, and culture. Palgrave Macmillan, London, 231-232. DOI: https://doi.org/10.1057/9780230504929_14

[5] Desmita.(2013). Psikologi Perkembangan. Bandung: Remaja Rosdakarya Offset

[6] Dhiva An A. (2015). Ketahui Parameter Utama Tumbuh Kembang Anak. Avaliable from https://www.parentingclub.co.id/smartstories/ketahui-parameter-utama-tumbuhkembang-anak (accesssed 29 July 2018)

[7] Hendriyani, E. H., dkk. (2012). Children's media use in Indonesia. Asian Jurnal of Communication, 22(3), 304-339. DOI: https://doi.org/10.1080/01292986.2012.662514

[8] Herlanti Yanti. (2016). Blogquest+: Pemanfaatan Media Sosial pada pembelajaran Sains Berbasis Isu Sosiosaintifik untuk Mengembangkan Keterampilan Berargumentasi dan Literasi Sains. Pendidikan IPA SPs Universitas Pendidikan Indonesia.

[9] Hermoyo, R. P. (2015). Membentuk komunikasi yang efektif pada masa perkembangan anak usia dini. Jurnal Pedagogi, 1(1), 1-21. Retrieved from http://journal.umsurabaya.ac.id/index.php/Pedagogi/article/view/ 21

[10] Kamus Besar Bahasa Indonesia. (2018). Avaliable from http://kbbi.web.id/media (accessed on 28 July 2018).

[11] Kaplan, A dan Haenlein, M. 2010. Users of the World, unite! The Challenges and Opportunities of Social Media" Business Horizons 53. Hlm: 59-68.

[12] Mengenal 6 Jenis Media Sosial. (2015).Available from http://yellowcabin.com/mengenal-6-jenismedia-sosial/ (accessed on 28 July 2018)

[13] Nahriyah S. (2017). Tumbuh Kembang Anak di Era Digital. Risâlah, Jurnal Pendidikan dan Studi Islam. 4(1). 65-74.

[14] Pengertian Media Sosial, Fungsi, Karakteistik, Jenis, \& Dampak Media Sosial. (2017). Avaliable from http://www.artikelsiana.com/2017/09/pengertian -media-sosial-fungsi.html (Accessed 28 July 2018)

[15] Rachman, D. M. P. (2016). Tantangan mendidik anak di era digital. Avaliable from: http://www.mungilmu.com/singlepost/2016/10/22/Tantangan-Mendidik-Anak-diEra-Digital (accessed 29 July 2018)

[16] Rowan, C. (2013). The impact of technology on child sensory and motor development. Retrieved March 10, 2017, avaliable from http://www.sensomotorischeintegratie.nl/CrisRowan.pdf (accessed 27 July 2018)

[17] Seefeldt, C., Wasik, B. A., \& Seefeldt, C. (2006). Early education : three-, four-, and fiveyear-olds go to school. (S. Darwin, Ed.). Pearson/Merrill/Prentice Hall. Retrieved from https://books.google.co.id/books?id=Je-

KAAAACAAJ \&dq=

Carol+Seefeldt+\%26+Barbara+A.+Wasik.\&hl= id\&sa $=$ X\&ved $=$

0ahUKEwino6ixsLjYAhVIwI8KHYp AAIQ6AEIKjAA

[18] Setyaningsih Lilis. (2015). Kenali Generasi NET. Avaliable from http://wartakota.tribunnews.com/2015/04/19/ke nali-generasi-net (accessed on 29 July 2018)

[19] Soetjiningsih. 1995. Tumbuh Kembang Anak. EGC. Jakarta

[20] Tapscott Don. (2009). Groen Up Digital How the Net Generation is Change Your World. USA. McGraw Hill Professional.

[21] Unantenne, N. (2014). Mobile Device Usage Among Young Kids: A Southeast Asia Study. The Asian Parent Insight. Avaliable from: https://s3-ap-southeast-1.amazonaws.com/tapsgmedia/theAsianparent+Insights+Device+Usage + A+Southeast+Asia+Study+November+2014.p df (accessed on 29 July 2018)

[22] Wikipedia. (2018). Avaliable from $\begin{array}{llll}\text { http://id.wikipedia.org/wiki/Media_sosial } & \\ \text { (accessed on } 28 \text { July } & & \end{array}$ 